\title{
EVAC Regimen
}

National Cancer Institute

\section{Source}

National Cancer Institute. EVAC Regimen. NCI Thesaurus. Code C64844.

A regimen consisting of etoposide, vincristine, doxorubicin and cyclophosphamide used for the treatment of extensive-stage small cell lung cancer. 